\title{
Study Kekuatan Bending Dan Struktur Mikro Komposit Polyethylene Yang Diperkuat Oleh Hybrid Serat Sisal Dan Karung Goni
}

\author{
I Gede Widiartha*, Nasmi Herlina Sari**, Sujita*** \\ Jurusan Teknik Mesin, Fakultas Teknik, Universitas Mataram \\ Alamat: JI. Majapahit No. 62, Mataram, Telp. 0370-636087
}

\begin{abstract}
The purpose of this study is to investigate and study the mechanical properties of polyethylene strukrur micro hybrid composites reinforced by fibers sisal and jute sacks.

Preparation of composites by hand lay-up method with a ratio of fiber volume fraction of sisal and jute sacks 30\%: 0\%, 20\%: 10\%, 15\%: 15\%, 10\%: 20\%, 0\%: 30\%. With unidirectional sisal fiber orientation and fiber length random burlap gunny sack fibers $2 \mathrm{~cm}$. Specimen testing is performed with a standard bending test ASTM D790, and microstructure.

Test results obtained from the average bending strength of composites with high fiber volume ratio fraksin 30\%: $0 \%$ is $74.43 \mathrm{Mpa}$. While the lowest average for bending strength found in composites with fiber volume fraction of 0\%: 30\%, the bending strength of $32.21 \mathrm{MPa}$. Therefore we can conclude the increasing volume fraction of sisal fiber with unidirectional fiber orientation, the higher the bending strength of its appeal and reverse the growing volume of burlap fibers with random orientation of the fibers feeding the lower the bending strength and the strength.
\end{abstract}

Keywords: composites, fiber, bending strength, tensile strength, microstructure.

\section{Pendahuluan}

Komposit merupakan suatu material didunia teknik yang dibuat dengan penggabungan dua macam bahan yang mempunyai sifat berbeda menjadi satu material baru dengan sifat yang berbeda pula. Komposit dari bahan serat terus diteliti dan dikembangkan guna menjadi bahan alternatif pengganti bahan logam, hal ini disebabkan sifat komposit serat yang lebih kuat dan ringan dibandinggkan dengan logam.Bahan komposit telah digunakan dalam industri pesawat terbang,otomotif, maupun alat-alat olahraga.penggunaan komposit diberbagai bidang tidak lepas dari sifat-sifat unggul yang di miliki komposit yaitu ringan, kuat, kaku, serta tahan terhadap korosi.

Penelitian yang mengarah terhadap pengembanggan komposit telah dilakukan, terutama komposit penguat serat alam. Penelitian ini dilakukan seiring dengan majunya eksploitasi penggunaan bahan alam alam dalam kehidupan sehari-hari. Keuntungan mendasar yg dimiliki oleh serat alam adalah jumlah berlimpah, dapat diperbaharui dan di daur ulang serta tidak mencemari lingkungan. Untuk memperoleh sifat mekanik yang tinggi maka serat alam telah diberi berbagai macam perlakuan yang dapat meningkatkan sifat mekaniknya.

Penelitian terdahulu/terkait dengan penelitian ini, seperti yg dilakukan oleh Murherje dan Satyanarayana, 1984. Dimana dalam penelitiannya mereka meneliti serat sisal. Sisal merupakan salah satu serat alam yang paling banyak digunakan dan paling mudah dibudidayakan. Serat sisal merupakan serat keras yang di hasilkan dari proses ekstraksi dari daun tanaman sisal (agave sisalana). Tanaman sisal dapat menghasilkan 200-250 daun dimana masing-masing daun terdiri dari 1000-1200 bundel serat yang mengandung $4 \%$ serat, $0,75 \%$ kultikula, $8 \%$ material kering, $87,25 \%$ air. (Murherjee dan Satyanarayana, 1984).

Nasmi H. S. 2011, mengkaji ketahanan bending komposit hybrid serat batang kelapa/serat gelas dengan matrik urea formaldheyde. Dimana dari hasil penelitianya menunjukan bahwa kekuatan bending tertinggi komposit hybrid serat batang kelapa/serat gelas pada fraksi volume serat batang kelapa/serat gelas $10: 20 \%$ yaitu 22,7 Mpa, kemudian berturut-turut 15:15 dan 20:10 yaitu 19,6 Mpa dan 17,37 Mpa.

Selain serat sisal, pemanfaatan serat karung goni merupakan langgah yang baik juga guna meninggkatkan fungsinya yang selama ini hanya digunakan sebagai karung pembungkus. Saat ini industri karung goni yang masih beroprasi tinggal dua yaitu PK. Rossela Baru Surabaya, dan satu lagi di Banten.Tutupnya beberapa industri karung gone disebabkan oleh kalah bersaingnya dengan karung plastik. Pengembangan riset dan teknologi dengan memanfaatkan produk lokal merupakan langkah bijak guna meningkatkan nilai jual material lokal.(Arif Wicaksono, 2006) 
Berdasarkan uraian yang telah dikemukakan pada latar belakang diatas maka dapat dirumuskan suatu permasalahan yang menjadi objek dalam penelitian ini adalah bagaimana pengaruh fraksi volume serat terhadap sifat mekanik dan struktur mikro komposit hybrid serat sisal-karung goni dengan matrix polyethylene.

Untuk menghindari permasalahan yang meluas dalam penelitian ini perlu diberikan batasan-batasan masalah sebagai berikut :

1. Pengujian yang dilakukan adalah uji bending, uji tarik, dan struktur mikro.

2. Serat yang digunakan adalah serat sisal dan serat karung goni dengan arah serat sisal searah dan karung goni dengan arah diacak.

3. Resin yang dipake adalah polyethylene.

4. Konsentrasi $\mathrm{NaOH}$ adalah $4 \%$ dengan waktu perendaman 1 jam.

5. Pembuatan komposit dilakukan secara manual.

6. Panjang serat sisal disesuaikan dengan cetakan.

7. Panjang serat karung goni $2 \mathrm{~cm}$.

Adapun yang menjadi tujuan dalam penelitian ini adalah untuk mengetahui Study sifat makanik dan struktur mikro komposit Polyethylene diperkuat serat sisal dan serat karung goni.

\section{Dasar Teori \\ Komposit}

Komposit merupakan sejumlah sistem multifasa sifat gabungan, yaitu gabungan antara bahan matrik atau pengikat dengan penguat unsur utama. Bahan komposit adalah serat karena serat menentukan karakteristik bahan komposit seperti kekakuan, kekuatan serta sifat-sifat mekanik yang lain. Matrik bertugas melindungi dan mengikat serat agar dapat bekerja dengan baik, dan meneruskan gaya dari suatu serat ke serat lain. Matrik dapat berupa keramik dan logam di samping berupa polimer.

Gabungan antara serat dan matrik disebut bahan komposit. Bahan komposit menggabungkan keunggulan kekuatan dan kekakuan serat dengan massa jenis yang rendah. Hasilnya suatu bahan yang ringan tetapi kuat dan kaku. Dengan kata lain, bahan ini mempunyai harga spesifik modulus dan modulus strength yang lebih besar dibandingkan dengan bahan lain.

Secara umum, dikenal tiga kelompok komposit, yaitu:

1. Komposit berserat yaitu komposit berpenguat serat antara lain seperti, serat gelas (fiber glass), serat karbon, serat grafit sampai serat baja.

2. Komposit laminer atau laminat yaitu komposit berpenguat dalam bentuk lembaran seperti kertas, kain.

3. Komposit partikel atau partikulat yaitu komposit berpenguat dalam bentuk butiran seperti kerikil, pasir, filler dalam bentuk kontinyu.

Pada umumnya bahan komposit terdiri dari dua unsur, yaitu serat (fiber) dan bahan pengikat serat tersebut yang disebut matrik.

1. Serat

Salah satu unsur penyusun bahan komposit adalah serat. Serat inilah yang terutama menentukan karakteristik bahan komposit, seperti kekakuan, kekuatan serta sifat-sifat mekanik lainnya. Serat inilah yang menahan sebagian besar gaya-gaya yang bekerja pada bahan komposit.

Banyak jenis serat baik serat alam maupun serat sintetik. Serat alam yang utama adalah kapas, wol, sutra dan rami (hemp), sedangkan serat sintetik adalah rayon, polyester, akril, dan nilon. Masih banyak serat lainnya dibuat untuk memenuhi keperluan sedangkan yang disebut di atas adalah jenis yang paling dikenal.

Secara garis besar dapat disebutkan bahwa serat alam adalah kelompok serat yang dihasilkan dari tumbuhan, binatang dan mineral. Penggunaan serat alam di industri tekstil dan kertas secara luas tersedia dalam bentuk serat sutera, kapas, kapuk, rami kasar (flax) goni, rami halus dan serat daun.

Komposit dengan penguat serat (fibrous composite) sangat efektif, karena bahan dalam bentuk serat jauh lebih kuat dan kaku dibanding bahan yang sama dalam bentuk padat (bulk). Kekuatan serat terletak pada ukurannya yang sangat kecil, kadang-kadang dalam orde mikron. Ukuran yang kecil tersebut menghilangkan cacat-cacat dan ketidaksempurnaan kristal yang biasa terdapat pada bahan berbentuk padatan besar, sehingga serat menyerupai kristal tunggal yang tanpa cacat, dengan demikian kekuatannya sangat besar.

2. Matriks (Resin)

Matriks (resin) dalam susunan komposit bertugas melindungi dan mengikat serat agar dapat bekerja dengan baik. Matriks harus bisa 
meneruskan beban dari luar ke serat. Umumnya matriks terbuat dari bahanbahan yang lunak dan liat. Polimer (plastik) merupakan bahan umum yang biasa digunakan. Matriks juga umumnya dipilih dari kemampuannya menahan panas. Polyester, vinilester dan epoksi adalah bahan-bahan polimer yang sejak dahulu telah dipakai sebagai bahan matriks.

\section{Serat Sisal}

Tanaman Sisal yang juga mempunyai nama lain, yaitu Agave sisalana Perrine, pada umumnya termasuk jenis tanaman semusim. Menurut sejarah, tanaman ini berasal dari Brazil dan dibawa ke Indonesia oleh para pelaut Spanyol dan Portugis sekitar tahun 1599. Di Indonesia tanaman tersebut sudah banyak dibudidayakan, terutama di pulau Jawa dan Sumatera yang antara lain terdapat di daerah Subang, Majalengka, Purwakarta, Purbalingga, Bengkulu, Lampung dan Palembang, yang merupakan salah satu sumber daya alam yang cukup berpotensi (Anonim, 2006).

Tanaman Sisal akan dibongkar setelah dua atau tiga kali panen untuk diganti tanaman baru, oleh karena itu limbah daun Sisal terus berkesinambungan sehingga cukup potensial untuk dimanfaatkan sebagai produk tekstil yang dapat memberikan nilai tambah (Doraiswarmy dkk., 1993).

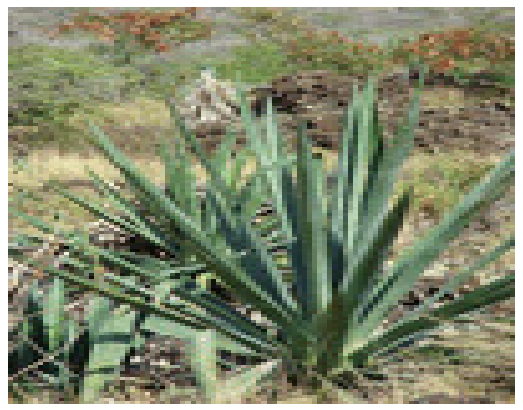

Gambar 1. Tanaman sisal

Daun sisal mempunyai lapisan luar yang terdiri dari lapisan atas dan bawah. Diantara lapisan tersebut terdapat banyak ikatan atau helai-helai serat (bundles of fibre) yang terikat satu dengan yang lain oleh sejenis zat perekat (gummy substances) yang terdapat dalam daun.

Karena daun sisal tidak mempunyai tulang daun, adanya serat-serat dalam daun sisal tersebut akan memperkuat daun sisal saat pertumbuhannya Dari berat daun sisal hijau yang masih segar akan dihasilkan kurang lebih sebanyak 2,5 sampai 3,5\% serat serat daun sisal.

Pengambilan serat daun Sisal pada umumnya dilakukan pada usia tanaman berkisar antara 1 sampai 1,5 tahun. Serat yang berasal dari daun sisal yang masih muda pada umumnya tidak panjang dan kurang kuat. Sedang serat yang dihasilkan dari tanaman sisal yang terlalu tua, terutama tanaman yang pertumbuhannya di alam terbuka dengan intensitas matahari cukup tinggi tanpa pelindung, akan menghasilkan serat yang pendek kasar dan getas atau rapuh (Doraiswarmy dkk., 1993).

\section{Karung Goni}

Pemanfaatan serat karung goni merupakan langgah yang baik juga guna meninggkatkan fungsinya yang selama ini hanya digunakan sebagai karung pembungkus. Saat ini industri karung goni yang masih beroprasi tinggal dua yaitu PK. Rossela Baru Surabaya, dan satu lagi di Banten.Tutupnya beberapa industri karung goni disebabkan oleh kalah bersaingnya dengan karung plastik. Pengembangan riset dan teknologi dengan memanfaatkan produk lokal merupakan langkah bijak guna meningkatkan nilai jual material lokal (Arif Wicaksono, 2006).

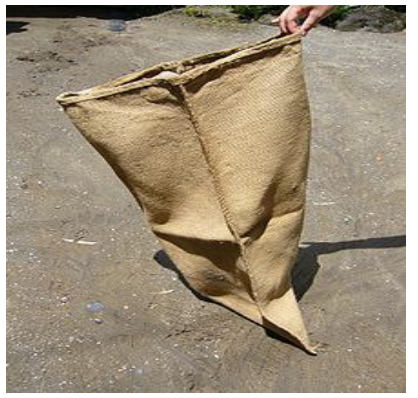

Gambar 2. Karung goni

Kain karung Goni dibuat dari serat kulit batang (bast fiber) dari tanaman Kenaf (Hibiscus Canabinus), banyak tumbuh di daerah tropis seperti Indonesia. Umumnya panjang serat ini (individual cells) 3-5 mm dengan mengandung lignin $13 \%$ dan sebagian besar terdiri dari sellulosa $71 \%$. (Anonim).

\section{Polyethylene}

Polyethylene adalah material yang berwarna putih dan mengkilap, mempunyai density sebesar 0,91-0,96. Jika densitynya meningkat maka kekakuan, kekerasan, dan 
kekuatan, distorsi panas dan kemampuan untuk menstransmisikan gas juga meningkat. Jika densitynya diturunkan maka kekuatan impack dan stress cracked resistance akan meningkat.

Stress cracket resistance adalah perubahan permukaan yang dialami Polyethylene dan beberapa jenis plastik lainnya pada saat dislubungi minyak dan jenis hidrokarbon yang lainnya.

adalah :

Sifat-sifat dari material polyethylene

1. Sangat kuat pada tempratur rendah.

2. Ketahanan kimia yang sangat baik.

3. Permeabilitas terhadap gas dan udara.

4. Penyusutan yang baik.

5. Mempunyai fleksibilitas yang baik pada suhu rendah

6. Mempunyai ketahanan elektrik yangt baik.

7. Mudah diwarnai.

8. Tidak berbau dan berasa.

Polyethylene dibedakan menjadi 2

yaitu Low Density dan High Density Polyethylene.

- Low Density Polyethylene (LDPE)

LDPE mulai meleleh pad atempratur $115^{0} \mathrm{C}$ dengan density antara 0,91-0,94. Dapat larut diberbagai macam pelerut pada tempratur diatas $100^{\circ} \mathrm{C}$. Sifat mekanik dari LDPE adalah ketangguhan yang baik dan tetap lunak pada range tempratur yang lebar.

- High Density Polyethylene (HDPE)

- HDPE mulai meleleh pada tempratur $127^{0} \mathrm{C}$ dengan density antara 0,95-0.97. Sifat mekanik HDPE adalah lebih kaku bila dibandingkan dengan LDPE, tetapi mempunyai kekuatan dan kekerasan yang lebih baik.

\section{Uji bending}

Pengujian bending adalah salah satu pengujian yang sudah lama dipakai karena dapat dilakukan pada bahan uji berbentuk standar dan tidak perlu menggunakan mesin uji khusus atau mesin uji seperti biasanya (Supardi, E, 1999).

Pengujian suatu bahan dimaksudkan untuk memperoleh kepastian mengenai sifatsifat dan kekuatan bahan tersebut. Melalui pengujian yang teliti akan diketahui apakah bahan tersebut dapat digunakanuntuk suatu konstruksi tertentu.

Pengujian bending (bengkok) static merupakan salah satu pengujian yang dipakai sejak lama karena dapat dilakukan terhadap batang uji berbentuk sederhana. Pengujian bengkok dapat dilakukan terhadap bahan getas dan untuk bahan liat dimaksudkan agar dapat menentukan adanya cacat dan retakan pada permukaan material. Pengujian bengkok pada bahan keras dan getas adalah cara terbaik untuk menentukan kekuatan dan kegetasan.

Untuk mengetahui kekuatan bending dapat dilakukan pengujian dengan mesin uji Torsee. Pada pengujian bending, bagian atas spesimen akan mengalami tegangan tekan dan bagian bawah akan mengalami tegangan tarik.

Bentuk spesimen pengujian ketahanan bending sesuai dengan standar ASTM D 790.

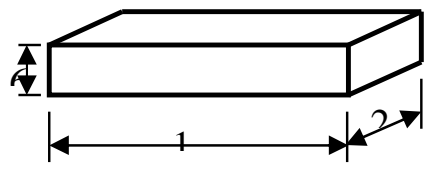

Gambar 3. Spesimen uji bending ASTM D 790

Kekuatan bending suatu material dapat dihitung dengan persamaan berikut:

$\sigma=\frac{M c}{I}$

Keteranyaı.

$\sigma=$ Kekuatan bending, $\mathrm{MPa}$

$\mathrm{M}=$ Momen, N.mm

$\mathrm{I}=$ Inersia, $\mathrm{mm}^{4}$

c = Jarak dari sumbu netral ke tegangan serat, $\mathrm{mm}$

Pada material yang homogen pengujian batang sederhana dengan dua titik dudukan dan pembebanan pada tengahtengah batang uji (three point bending), maka tegangan maksimum dapat dihitung dengan persamaan berikut (ASTM D 790):

$$
\begin{aligned}
& \sigma=\frac{3 P L}{2 b d^{2}} \\
& \text { Keterangan: } \\
& \sigma=\text { Kekuatan bending, MPa } \\
& \mathrm{P}=\text { Beban, } \mathrm{N} \\
& \mathrm{L}=\text { Panjang span, } \mathrm{mm} \\
& \mathrm{b}=\text { lebar batang uji, } \mathrm{mm} \\
& \mathrm{d}=\text { tebal batang uji, } \mathrm{mm}
\end{aligned}
$$

\section{Proses Pembuatan Spesimen}

Setelah serat sisal selesai diperlakukan alkali, kemudian serat dipotongpotong sesuai dengan panjang cetakan, dan serat karung goni dipotong sepanjang $20 \mathrm{~mm}$. Selanjutnya searat ditimbang sesuai dengan fraksi volume serat 10, 15, 20, 30 (\% volume) 
dan kemudian diaduk secara manual selama 10 menit untuk serat karung goni acak sampai campuran dianggap homogen dan dituangkan kedalam cetakan. Kemudian campuran tersebut dituangkan ke dalam cetakan dan di atasnya diletakan serat sisal searah yang panjangnya sesuai dengan panjang cetakan, selanjutnya dituangkan lagi serat karung goni yang telah dicampur resin.

Serat karung goni+ resin polyetylene

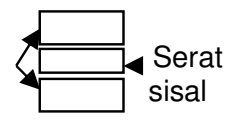

Gambar 6. Langkah pembuatan spesimen

\section{Hasil Uji Bending}

Pengujian

Bending dilakukan menggunakan alat uji bending dengan merk Hung Ta Instrument. Data hasil uji bending yang diambil merupakan kekuatan bending rata-rata dari tiga spesimen. Data-data dari pengujian kemudian dimasukkan dalam persamaan-persamaan sehingga diperoleh besarnya kekuatan bending seperti pada tabel berikut :

Tabel 2. Rata-rata kekuatan bending

\begin{tabular}{|c|c|c|}
\hline \multirow{2}{*}{$\begin{array}{c}\text { Fraksi Volume } \\
\text { Serat Sisal dan } \\
\text { Karung Goni } \\
(\%)\end{array}$} & \multicolumn{2}{|c|}{ Kekuatan Bending } \\
\hline & Mpa & $\begin{array}{l}\text { Rata-Rata } \\
\text { (Mpa) }\end{array}$ \\
\hline \multirow{3}{*}{$30: 0$} & 65,13 & \\
\hline & 76,16 & 74,43 \\
\hline & 82,01 & \\
\hline \multirow{3}{*}{$20: 10$} & 53,7 & \\
\hline & 57,28 & 55,22 \\
\hline & 54,68 & \\
\hline \multirow{3}{*}{$15: 15$} & 49,33 & \\
\hline & 46,21 & 46,38 \\
\hline & 43,61 & \\
\hline \multirow{3}{*}{$10: 20$} & 40,03 & \\
\hline & 43,93 & 41,87 \\
\hline & 41,66 & \\
\hline \multirow{3}{*}{$0: 30$} & 33,51 & \\
\hline & 30,91 & 32,21 \\
\hline & 32,21 & \\
\hline
\end{tabular}

Dimana kekuatan bending rata-rata tertinggi terdapat pada komposit dengan fraksi volume serat hybrid dengan perbandingan serat sisal dan karung goni $30 \%$ : $0 \%$ yaitu 74,43 Mpa. Kemudian kekuatan bending terendah terdapat pada komposit dengan perbandingan serat hybrid secara berrurutan yaitu 20\%: 10\%, 15\%: $15 \%$, $10 \%: 20 \%$, dan $0 \%: 30 \%$, dengan masing-masing kekuatan bending sebesar 55,22 Mpa, 46,38 Mpa, 41,87 Mpa, dan 32,21 Mpa.

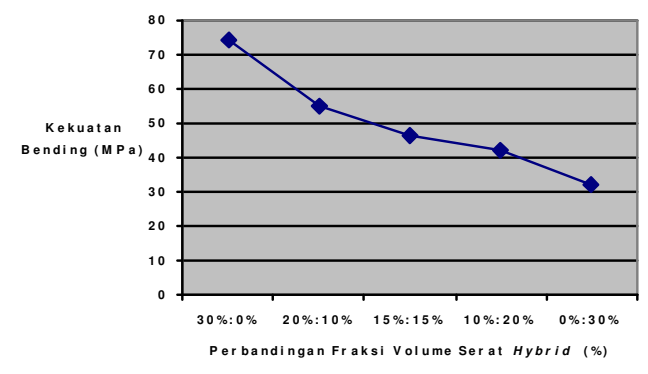

Gambar 7. Hubungan kekuatan bending dengan perbandingan fraksi volume serat sisal dan karung goni pada material komposit polyethylene.

Dengan demikian terdapat penurunan kekuatan bending yang terjadi, hal ini dikarenakan semakin banyak serat sisal dengan orientasi serat searah, maka smakin tinggi kekuatan bendingnya. Seperti yang ditunjukan pada gambar 8 , dimana seluruh serat yang digunakan adalah serat sisal dengan orentasi serat searah.

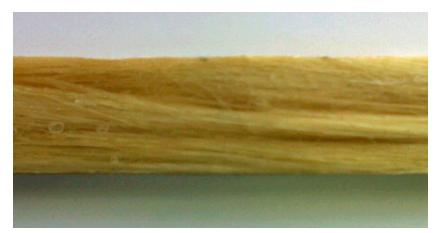

Gambar 8. Spesimen uji bending komposit hybrid serat sisal dan karung goni dengan perbandingan serat $30 \%$ : $0 \%$, yang telah diuji bending

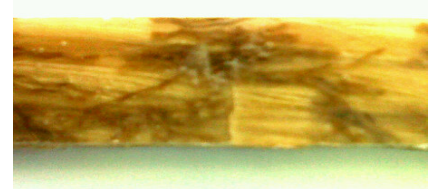

Gambar 9. Spesimen uji bending komposit hybrid serat sisal dan karung goni dengan perbandingan serat $20 \%: 10 \%$, yang telah diuji bending

Pada gambar 8 Spesimen uji bending komposit hybrid serat sisal dan karung goni dengan perbandingan serat $30 \%: 0 \%$, tidak mengalami retakan setelah di uji bending dengan rata-rata kekuatan bending tertinggi di antara yang lain, yaitu sebesar 74,43 Mpa. Hal ini disebabkan karena seluruh seratnya menggunakan serat sisal dengan orentasi serat searah, yang bekerja secara optimal dan mampu menahan beban yang diberikan. Selanjutnya pada spesimen dengan 
perbandingan serat sisal dan karung goni $20 \%$ : $10 \%$ mengalami penurunan sebesar $25,8 \%$ dari spesimen dengan perbandingan serat sisal dan karung goni 30\%:0\%.

Penurunan diakibatkan karena adanya void akibat dari kurang sempurnanya ikatan antar serat dengan resin, dan juga berkurangnya serat sisal dan terdapat serat karung goni sebesar $10 \%$. Penyebaran serat karung goni secara acak menyebabkan tidak meratanya serat karung goni pada spesimen, yang mengakibatkan serat tidak mampu menjalankan peranannya secara maksimal sebagai penerus gaya. Selanjutnya pada spesimen dengan perbandingan serat sisal dan karung goni $15 \%$ : $15 \%$ mengalami penurunan sebesar $16,1 \%$ dari spesimen dengan perbandingan serat sisal dan karung goni $20 \%$ : $10 \%$.

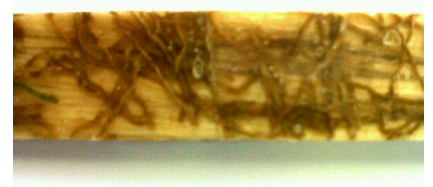

Gambar 10. Spesimen uji bending komposit hybrid serat sisal dan karung goni dengan perbandingan serat $15 \%$ : $15 \%$, yang telah diuji bending

Kegagalan spesimen diakibatkan adanya void, dengan diawali dengan retakan mikro yang dapat dilihat dengan mata, seperti pada saat melakukan pengujian yang di tunjukan pada gambar 10. Penurunan ini diakibatkan fraksi volume serat searah dengan serat acak sama jumlahnya sehingga kekuatannya bendingnyapun ikut menurun dibandingkan dengan spesimen yang fraksi volume serat searahnya lebih banyak. Selanjutnya pada spesimen dengan perbandingan serat sisal dan karung goni $10 \%$ : $20 \%$ mengalami penurunan sebesar $9,8 \%$ dari spesimen dengan perbandingan serat sisal dan karung goni 15\%:15\%.

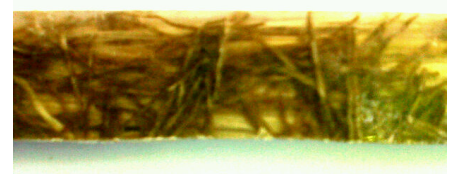

Gambar 11. Spesimen uji bending komposit hybrid serat sisal dan karung goni dengan perbandingan serat $10 \%: 20 \%$, yang telah diuji bending
Pada gambar 11 terdapat retakan pada spesimen akibat uji bending. Posisi retakan pada spesimen ini sejajar dengan serat karung goni yang dapat dilihat pada gambar 11. Hal ini disebabakan jumlah serat karung goni lebih banyak dibandingkan dengan jumlah serat sisal, yang mengakibatkan serat tidak dapat meneruskan gaya secara maksimal. Kemudian pada spesimen dengan perbandingan serat sisal dan karung goni $0 \%$ : 30\% mengalami penurunan sebesar $23,07 \%$ dari spesimen dengan perbandingan serat sisal dan karung goni $10 \%$ : $20 \%$.

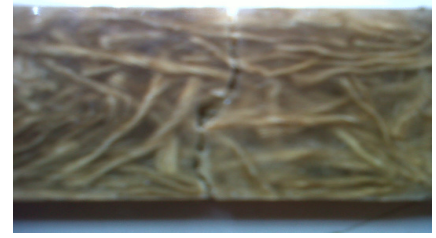

Gambar 12. Spesimen uji bending komposit hybrid serat sisal dan karung goni dengan perbandingan serat $0 \%: 30 \%$, yang telah diuji bending

Pada gambar 12 terdapat retakan yang cukup besar pada spesimen akibat uji bending dengan rata-rata kekuatan bending terendah bila dibandingkan dengan yang lain. Hal ini disebabkan karena penyebaran serat karung goni yang pendek dengan panjang 2 $\mathrm{cm}$, dengan orentasi serat acak dan penyebaran serat yang tidak merata menyebabkan serat tidak mampu menerima beban/gaya yang diberikan oleh resin bila dibandingkan dengan spesimen yang lain

\section{Uji Photo Mikro}

Photo mikro dari komposit dapat dapat memberikan sebagian informasi yang mendukung sifat dari komposit tersebut. Adapun hasil photo mikro yang dihasilkan dari pengamatan metalografi yang dilakukan sebagai berikut :

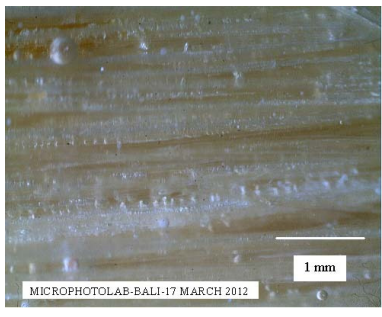

Gambar 13. Photo mikro komposit hybrid serat sisal dan karung goni dengan perbandingan serat 30\%: $0 \%$. 
Dari pengamatan struktur mikro spesimen dengan fraksi volume serat sisal $30 \%$ dan serat karung goni $0 \%(30 \%: 0 \%)$ seperti pada gambar di atas, dimana orentasi serat sisal yang searah tampak jelas, namun serat-serat tersebut kelihatan lebih menyatu satu dengan yang lain karena diakibatkan oleh proses penekanan, dan terlihat juga beberapa void yang terdapat pada spesimen tersebut.

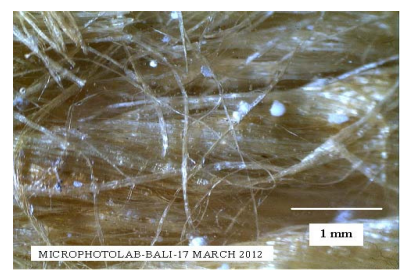

Gambar 14. Photo mikro komposit hybrid serat sisal dan karung goni dengan perbandingan serat $20 \%: 10 \%$.

Pada pengamatan photo mikro spesimen komposit dengan fraksi volume serat sisal Sisal 20\% : karung goni $10 \%$ (20\%:10\%) dengan pembesaran $30 \times$ seperti pada gambar di atas, terlihat ada void, dan letak serat karung goni yang tidak beraturan dengan diameter serat lebih besar bila di bandingkan dengan serat sisal yg mengakibatkan hampir tertutupnya serat sisal sehingga serat sisal tampak tidak terlalu jelas.

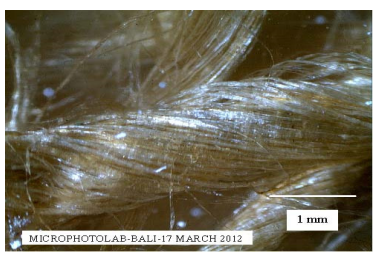

Gambar 15. Photo mikro komposit hybrid serat sisal dan karung goni dengan perbandingan serat $15 \%: 15 \%$.

Pada pengamatan struktur mikro speimen komposit dengan fraksi volume serat sisal $15 \%$ : serat karung goni $15 \%$ (15\%:15\%) pada gambar di atas mikrostruktur serat karung goni terlihat jelas dan terdapat beberapa voit yang dapat mempengaruhi kekuatan dari spesimen tersebut.

Dari pengamatan struktur mikro spesimen dengan fraksi volume serat sisal $10 \%$ dan serat karung goni $20 \%$ (10\%:20\%) seperti pada gambar di atas, dimana terdapat beberapa void yang di akibatkan oleh penekanan yang tidak merata sewaktu pencetakan komposit sehingga terdapat rongga-rongga udara. Dari pengamatan struktur mikro spesimen dengan fraksi volume serat sisal $10 \%$ dan serat karung goni $20 \%$ (10\%:20\%) seperti pada gambar di atas, dimana terdapat beberapa void yang di akibatkan oleh penekanan yang tidak merata sewaktu pencetakan komposit sehingga terdapat rongga-rongga udara.

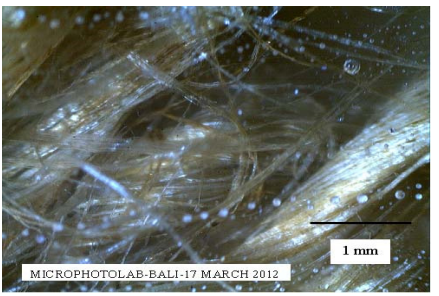

Gambar 16. Photo mikro komposit hybrid serat sisal dan karung goni dengan perbandingan serat $10 \%: 20 \%$.

Pada pengamatan struktur mikro speimen komposit dengan fraksi volume serat sisal $0 \%$ : serat karung goni 30\% (0\%:30\%) pada gambar di atas tampak jelas serat karung goni karena pada komposit ini tidak menggunakan serat sisal hanya menggunakan serat karung goni saja, dengan orentasi serat acak.

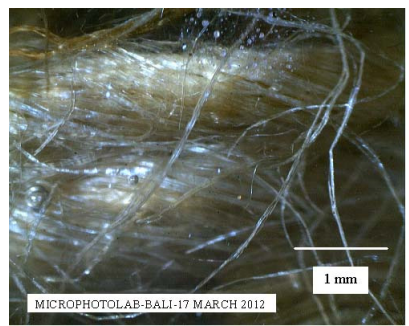

Gambar 17. Photo mikro komposit hybrid serat sisal dan karung goni dengan perbandingan serat $0 \%: 30 \%$.

\section{Kesimpulan}

Berdasarkan data dari analisa dan pembahasan yang telah dilakukan maka hasil penelitian ini dapat disimpulkan sebagai berikut :

Komposit hybrid serat sisal dan karung goni dengan orientasi serat sisal searah dan serat karung goni acak dapat menunjukan bahwa semakin besar fraksi volume serat sisal maka kekuatan tarik dan kekuatan bending semakin tinggi. Yang artinya bahwa semakin besar fraksi volume serat karung goni maka kekuatan bending 
dan tariknya semakain rendah. Sedangkan morfologi ikatan antara resin dan serat ditunjukan dalam gambar photo mikro.

\section{Dartar Pustaka}

Achmad, 2010, Variasi Panjang Serat Daun Pandan Wangi Terhadap Ketangguhan Retak Dan Ketahanan Bending Material Komposit Dengan Matrik Polyester Dan Epoxy, Tugas Akhir, Jurusan Teknik Mesin Fakultas Teknik Universitas Mataram, Mataram

Annur D., Judawisastra H., Abdullah D., 2009, Optimasi Waktu Alkalisasi Terhadap Peningkatan Sifat Tarik Komposit Polyester Berpenguat Tekstil Serat Kenaf, Teknik Material Fakultas Teknik Mesin dan Dirgantara, Institut Teknologi Bandung, Bandung

Anonim, 2006, Budiaya Tanaman Kenaf.

Annur D., 2009, Sifat Mekanik Serat Alam.

Doraiswarmy dkk., 1993. Pineapple Leaf Fibres, Textile Progress Vol. 24 Number 1, Textile Institute.

Gibson, F.R., 1994, "Principles of Composite material Mechanis", International Edition", McGraw-Hill Inc, New York.

Hartomo, A. J. Rusdiharsono, A. Hardjanto, D. 1992, Memahami Polimer Dan Perekat, Andi Offset Yogyakarta.

http://journal.uii.ac.id/index.php/jurnalssteknoin/article/view/795/713.

H.M.M.A. Rashed, M. A. Islam and F. B. Rizvi, 2006, Journal of Naval Architecture and Marine Engineering.

Justus Kimia Raya, 2001, Technical Data Sheet, Jakarta.

Kusumastuti A., 2009, Aplikasi Serat Sisal Sebagai Komposit Polimer, Universitas Negeri Semarang.
Lokantara P., dan Suardana N. P. G., 2007, Analisis Arah Dan Perlakuan Serat Tapis Serat Rasio Epoxy Hardener Terhadap Sifat Fisis Dan Mekanis Komposit Tapis/Epoxy, Jurnal Cakram, Jurusan Teknik Mesin Universitas Udayana, Bali.

Murherjee dan Satyanarayan (dalam Adhi Kusumastuti, 2009, Aplikasi Serat Sisal Sebagai Komposit Polimer, Universitas Negeri Semarang).

Nasmi H. S., 2011, Ketahanan Bending Komposit Hybrid Serat Batang Kelapa/Serat Gelas Dengan Matrik Urea Formaldheyde, Teknik Mesin, Fakultas Teknik, Universitas Mataram.

Putra D. G. P., 2011, Analisis Pengaruh Fraksi Volume Serat Daun Nanas Terhadap Ketahanan Bending Dan Kekuatan Tarik Komposit Unsaturated Polyester (UPE), Tugas Akhir, Jurusan Teknik Mesin Fakultas Teknik Universitas Mataram, Mataram

Schwartz M., 1984 Composite Materials Handbook, McGraw-Hill Inc.,NewYork, USA

Surdia,T., 2000, Pengetahuan Bahan Teknik, Jakarta: Pradnya Paramita.

Supardi E., 1999, Pengujian Logam, Angkasa Bandung. Bandung.

Varghese et al, 1994 (dalam Adhi Kusumastuti, 2009, Aplikasi Serat Sisal Sebagai Komposit Polimer, Universitas Negeri Semarang).

Wicaksono, A., 2006 (dalam Adhi Kusumastuti, 2009, Aplikasi Serat Sisal Sebagai Komposit Polimer, Universitas Negeri Semarang) 